\title{
Hubungan antara Hipokalsemia dan Prognosis Buruk pada Sepsis Neonatal
}

\author{
Hermawan, Tetty Yuniati, Aris Primadi \\ Departemen Ilmu Kesehatan Anak Fakultas Kedokteran Universitas Padjadjaran/Rumah Sakit Dr. Hasan \\ Sadikin, Bandung
}

\begin{abstract}
Latar belakang. Sepsis neonatal merupakan salah satu penyebab utama morbiditas dan mortalitas pada neonatus. Pasien sakit kritis, terutama kondisi sepsis, sering dilaporkan terjadi gangguan regulasi kalsium berupa hipokalsemia.

Tujuan. Mengetahui hubungan antara hipokalsemia dengan prognosis buruk sepsis neonatal.

Metode. Penelitian dengan desain potong lintang dilaksanakan bulan Maret-Mei 2014 di RS Dr. Hasan Sadikin Bandung, dan RS Kota Bandung. Subjek neonatus cukup bulan usia $<28$ hari yang memenuhi kriteria sepsis neonatal, yaitu terdapat dua atau lebih kriteria systemic inflammatory response syndrome (SIRS) disertai bukti tanda infeksi berupa hasil kultur darah positif atau tersangka infeksi. Pemeriksaan kadar ion kalsium darah dilakukan saat hari pertama perawatan.

Hasil. Terdapat 40 subjek yang memenuhi kriteria inklusi, faktor yang berhubungan dengan prognosis buruk, yaitu kadar ion kalsium ( $p=0,012)$, onset sepsis $(p=0,002)$, dan berat badan bayi $(p=0,045)$. Analisis dengan metode regresi logistik ganda menunjukkan faktor risiko kejadian prognosis buruk pada sepsis neonatal adalah hipokalsemia (p=0,015; POR 36,17; IK95\% 2,01-650,19), sepsis awitan lanjut ( $p=0,003$; POR 44,86; IK 95\% 3,66-549,98), dan berat badan <2500 gram ( $\mathrm{p}=0,032$; POR 12,21; IK95\% 1,35-110,29).

Kesimpulan. Terdapat hubungan antara hipokalsemia dan prognosis buruk pada sepsis neonatal $(\mathrm{p}<0,05)$. Sari Pediatri 2015;16(6):421-6.
\end{abstract}

Kata kunci: hipokalsemia, prognosis buruk, sepsis neonatal

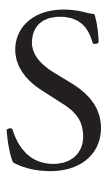
epsis neonatal merupakan masalah kesehatan anak global yang penting. Berdasarkan data dari World Health Statistic tahun 2011, angka kematian neonatal adalah 24 per 1000

\footnotetext{
Alamat korespondensi:

Dr. Hermawan. Departemen Ilmu Kesehatan Anak Fakultas Kedokteran Universitas Padjadjaran/Rumah Sakit Dr. Hasan Sadikin. Jl. Pasteur No. 38 Bandung 40161. E-mail:dr_hermawan_tan@yahoo.com
}

kelahiran hidup dan $80 \%$ kematian neonatal terjadi di negara berkembang. Kematian neonatal menyumbang lebih dari setengah angka kematian bayi $(59,4 \%)$, sedangkan jika dibandingkan dengan angka kematian balita, kematian neonatal menyumbangkan $47,5 \%$. Tiga penyebab utama kematian neonatal tersebut, antara lain akibat infeksi $(36 \%)$, prematuritas $(28 \%)$, dan asfiksia (23\%). ${ }^{1}$

Di Indonesia, angka kematian neonatal adalah 19 
per 1000 kelahiran hidup dan estimasi angka kematian bayi adalah 34 per 1.000 kelahiran hidup dengan $10,6 \%$ meninggal karena sepsis neonatal. ${ }^{1,2}$ Data angka kejadian sepsis neonatal RS Dr. Hasan Sadikin periode Januari-Desember 2011 adalah 490 bayi dari 1377 bayi usia $0-28$ hari yang dirawat inap pada periode yang sama $(35,6 \%)$ dengan angka kematian $12 \%{ }^{3}$

Prognosis bayi dengan sepsis neonatal, apabila hanya melalui gejala klinis, sulit ditentukan karena bayi dengan sepsis neonatal hanya menunjukkan gejala awal atau tanda bahaya yang minimal, tidak spesifik, samarsamar (subtle). Namun, sepsis neonatal membutuhkan perawatan yang lama di rumah sakit, bahkan selama perawatan dapat terjadi perburukan. ${ }^{4,5}$ Pada pasien dewasa sakit kritis, terutama sepsis, terjadi hipokalsemia dan terdapat korelasi hipokalsemia berat dengan peningkatan mortalitas. ${ }^{7}$ Pemeriksaan kadar kalsium secara rutin dilakukan pada kasus sepsis neonatal, tetapi tidak pernah diperhatikan hubungannya dengan prognosis. Tujuan penelitian ini untuk mengetahui hubungan antara hipokalsemia dan prognosis buruk sepsis neonatal. Penilaian prognosis yang tepat mendorong klinisi untuk melakukan pemantauan yang lebih ketat, terapi yang akurat dan menjadi dasar pertimbangan etik konseling untuk memberikan informasi mengenai keadaan penderita kepada orangtua dalam proses pengambilan keputusan, serta menentukan tindakan medis selanjutnya.

\section{Metode}

Penelitian desain potong lintang dilaksanakan pada bulan Maret-Mei 2014 di ruang Perinatologi, ruang neonatal intensive care (NICU), dan instalasi gawat darurat (IGD) Departemen Ilmu Kesehatan Anak RSUP Dr. Hasan Sadikin Bandung dan RSUD Kota Bandung. Kriteria inklusi meliputi bayi usia $<28$ hari yang memenuhi kriteria sepsis neonatal, yaitu terdapat dua atau lebih kriteria systemic inflammatory response syndrome (SIRS) disertai bukti tanda infeksi-berupa hasil kultur darah positif atau tersangka infeksi dapat berupa pneumonia, necrotizing enterocilitis (NEC), meningitis, atau chorioamnionitis. Gejala klinis tersangka infeksi pada sepsis yang paling sering ditemukan adalah respiratory distress. ${ }^{6}$ Variabel perancu pada penelitian ini adalah onset sepsis dan berat badan.

Seluruh subjek penelitian menjalani pemeriksaan fisis, meliputi tanda vital dan penilaian diagnosis sepsis neonatal. Pemeriksaan laboratorium rutin dilakukan untuk sepsis neonatal (hemoglobin, hematokrit, leukosit, trombosit, hitung jenis leukosit, morfologi darah tepi, gula darah serum sewaktu, natrium, kalium dan kultur resistensi darah). Pemeriksaan kadar ion kalsium darah dilakukan setelah memenuhi kriteria inklusi dan saat pasien dirawat hari pertama. Kadar ion kalsium pada masing-masing pasien dicatat. Untuk hasil ion kalsium $\geq 4,7 \mathrm{mg} / \mathrm{dL}$, masuk dalam kategori non hipokalsemia, sedangkan hipokalsemia apabila hasil ion kalsium $<4,7 \mathrm{mg} / \mathrm{dL}$. Selama pasien dirawat, perkembangan keadaan subjek diikuti, apabila selama perawatan terjadi gangguan disfungsi lebih dari satu sistem organ dan atau mengalami episode syok septik atau meninggal dimasukan dalam kategori prognosis buruk, begitupun sebaliknya pada prognosis baik. Orangtua/wali subjek penelitian telah bersedia anaknya diikutsertakan dalam penelitian dan menandatangani surat persetujuan (informed consent). Subjek penelitian dikumpulkan dengan cara consecutive sampling.

Analisis statistik menggunakan program SPSS for windows versi 17. Uji chi-kuadrat $\left({ }^{2}\right)$ digunakan untuk mencari hubungan dua variabel data kategorik, antara karateristik subjek dengan prognosis pasien. Uji eksak Fisher dilakukan jika syarat uji chi-kuadrat tidak terpenuhi. Uji- Mann-Whitney digunakan untuk membandingkan rata-rata data numerik dan prognosis pasien. Analisis regresi logistik ganda dengan prevalensi odds ratio dan interval kepercayaan 95\% digunakan untuk melihat hubungan antar variabel. Kemaknaan hasil uji ditentukan berdasarkan nilai $\mathrm{p}<0,05$.

\section{Hasil}

Didapatkan 42 subjek yang memenuhi kriteria inklusi. Dua subjek drop out disebabkan satu bayi pulang paksa dan satu rujuk ke rumah sakit lain. Empat puluh subjek yang diteliti terdiri atas 14 bayi berkriteria prognosis baik dan 26 prognosis buruk. Karakteristik subjek penelitian tertera pada Tabel 1 . Semua subjek yang masuk dalam penelitian ini adalah yang memenuhi kriteria diagnosis sepsis, yaitu mempunyai dua atau lebih kriteria SIRS disertai bukti tanda infeksi berupa hasil kultur darah positif atau tersangka infeksi (Tabel 2).

Faktor yang berhubungan dengan prognosis buruk pada sepsis neonatal meliputi kadar ion kalsium, onset sepsis dan berat badan tertera pada Tabel 3 . 
Tabel 1. Karakteristik subjek penelitian

\begin{tabular}{lcc}
\hline & \multicolumn{2}{c}{ Prognosis } \\
\cline { 2 - 3 } Karakteristik Subjek & $\begin{array}{c}\text { Buruk } \\
(\mathrm{n}=26)\end{array}$ & $\begin{array}{c}\text { Baik } \\
(\mathrm{n}=14)\end{array}$ \\
\hline Jenis kelamin & & \\
$\quad$ Laki-laki & 18 & 6 \\
$\quad$ Perempuan & 8 & 8 \\
Paritas & & \\
$\quad$ Primipara & 9 & 5 \\
$\quad$ Multipara & 17 & 9 \\
Tempat persalinan & & \\
$\quad$ Rumah sakit & 14 & 11 \\
$\quad$ Luar rumah sakit & 12 & 3 \\
Tingkat pendidikan (tahun) & & \\
$\quad \leq 9$ & 10 & 7 \\
$\quad>9$ (lulus SMP) & 16 & 7 \\
Cara persalianan & & \\
$\quad$ Per vaginam & 20 & 10 \\
$\quad$ Operasi & 6 & 4 \\
\hline
\end{tabular}

Tabel 3. Faktor yang berhubungan dengan prognosis sepsis neonatal

\begin{tabular}{lccc}
\hline \multirow{2}{*}{ Variabel } & \multicolumn{2}{c}{ Prognosis } & \multirow{2}{*}{ Nilai p* } \\
\cline { 2 - 3 } & $\begin{array}{c}\text { Buruk } \\
(\mathrm{n}=26)\end{array}$ & $\begin{array}{c}\text { Baik } \\
(\mathrm{n}=14)\end{array}$ & \\
\hline Kadar ion kalsium & & & \\
$\quad$ Hipokalsemia & 12 & 1 & $0,012^{* *}$ \\
$\quad \begin{array}{l}\text { Normal } \\
\text { Onset sepsis (hari) }\end{array}$ & 14 & 13 & \\
$\quad \leq 3$ \\
$\quad$ & 9 & 12 & $0,002^{*}$ \\
$\quad>3$ & 17 & 2 & \\
$\begin{array}{l}\text { Berat badan (g) } \\
\quad<2500\end{array}$ & 12 & 2 & $0,045^{* *}$ \\
$\quad \geq 2500$ & 14 & 12 & \\
\hline Keterangan: Analisis menggunakan *uji chi-kuadrat, ${ }^{* *}$ Uji eksak-Fisher
\end{tabular}

Tabel 2. Variabel untuk diagnosis pada sepsis neonatal

\begin{tabular}{|c|c|c|}
\hline \multirow[b]{2}{*}{ Variabel } & \multicolumn{2}{|c|}{ Prognosis } \\
\hline & $\begin{array}{l}\text { Buruk } \\
(\mathrm{n}=26)\end{array}$ & $\begin{array}{c}\text { Baik } \\
(\mathrm{n}=14)\end{array}$ \\
\hline \multicolumn{3}{|l|}{ Suhu $\left({ }^{\circ} \mathrm{C}\right)$} \\
\hline Median & 36,0 & 36,6 \\
\hline Rentang & $35,5-38,4$ & $36,5-38,7$ \\
\hline \multicolumn{3}{|l|}{ Frekuensi napas/menit } \\
\hline$\geq 60$ & 19 & 2 \\
\hline$<60$ & 7 & 12 \\
\hline \multicolumn{3}{|c|}{ Frekuensi jantung/menit } \\
\hline$\geq 160$ & 11 & 1 \\
\hline$<160$ & 15 & 13 \\
\hline \multicolumn{3}{|l|}{ Jumlah leukosit $\left(/ \mathrm{mm}^{3}\right)$} \\
\hline Median & $16.850,00$ & $27.200,00$ \\
\hline Rentang & $2.000-55.200$ & $3.600-40.000$ \\
\hline \multicolumn{3}{|l|}{ Feeding intolerance } \\
\hline $\mathrm{Ya}$ & 26 & 14 \\
\hline Tidak & 0 & \\
\hline \multicolumn{3}{|c|}{ Waktu pengisian kapiler (detik) } \\
\hline$\geq 3$ & 6 & 2 \\
\hline$<3$ & 20 & 12 \\
\hline \multicolumn{3}{|l|}{ Kultur darah } \\
\hline Positif & 13 & 0 \\
\hline Negatif & 13 & 14 \\
\hline \multicolumn{3}{|l|}{ Tersangka infeksi } \\
\hline Pneumonia & 19 & 2 \\
\hline NEC & 7 & 1 \\
\hline Chorioamnionitis & 0 & 11 \\
\hline
\end{tabular}


Tabel 4. Hubungan antara berbagai faktor risiko dengan kejadian prognosis buruk pada sepsis berdasarkan regresi logistik ganda

\begin{tabular}{lccc}
\hline Variabel & Koefisien B & Nilai P & POR (IK95\%) \\
\hline Hipokalsemia & 3,588 & 0,015 & $36,17(2,01-650,19)$ \\
Sepsis awitan lanjut & 3,804 & 0,003 & $44,86(3,66-549,98)$ \\
Berat badan $<2.500 \mathrm{~g}$ & 2,502 & 0,032 & $12,21(1,35-110,29)$ \\
\hline
\end{tabular}

Ket: akurasi model $=85 \% ; \mathrm{SE}=$ standar error $; \mathrm{POR}=$ prevalens odds ratio

Berdasarkan analisis uji chi kuadrat dan eksak Fisher terdapat tiga variabel bebas yang mempunyai faktor risiko yang berhubungan secara statistik dengan prognosis buruk yang kemudian dilakukan analisis regresi logistik ganda (Tabel 4).

Faktor risiko kejadian prognosis buruk pada sepsis yang bermakna secara statistik adalah hipokalsemia dengan faktor perancu terdiri atas sepsis awitan lanjut dan berat badan < 2500 gram, akurasi model penelitian ini adalah $85 \%$.

\section{Pembahasan}

Berdasarkan rancangan potong lintang dan analisis regresi logistik ganda, hipokalsemia mempunyai risiko terjadinya prognosis buruk 36,17 kali. Penelitian mengenai kadar ion kalsium yang berhubungan dengan outcome atau prognosis sepsis pada bayi maupun anak, sampai saat ini belum ditemukan. Laporan penelitian Moritoki $\mathrm{dkk}^{7}-\mathrm{kadar}$ ion kalsium dan keluaran pada orang dewasa yang sakit kritis termasuk di antaranya sepsis-mendapatkan banyak pasien sakit kritis mengalami hipokalsemia. Namun, laporan tersebut tidak berhubungan secara independen dengan kematian di rumah sakit. Analisis regresi logistik multivariat menunjukkan hanya kadar ion kalsium sangat rendah $<0,8 \mathrm{mmol} / \mathrm{L}(3,3 \mathrm{mg} / \mathrm{dL})$ yang secara independen terkait dengan kematian di rumah sakit.

Spasojevic $\mathrm{dkk}^{10}$ melaporkan bahwa patogen infeksi akan mengaktifkan IL-6 dan IL-8 yang mengaktifkan NF-kB sehingga terjadi peningkatan induksi nitrat oksida sintase (iNOS). Hipotalamus manusia mengandung banyak reseptor iNOS sehingga pada sepsis akan terjadi pengaktifan aksis hipothalamus pituitary adrenal (HPA) melalui induksi nitrat oksida sintase (iNOS). Nukleus paraventrikular di hipotalamus mengeluarkan corticotrophin releasing hormone (CRH) yang menstimulasi kelenjar hipofisis anterior untuk menyekresi adrenocorticotropine hormone $(\mathrm{ACTH})$ ke dalam sirkulasi. Pada kelenjar adrenal, ACTH menstimulasi sintesis dan pelepasan glukokortikoid. ${ }^{8,11}$ Pelepasan glukokortikoid berpengaruh pada metabolisme kalsium plasma dengan menghambat pembentukan dan aktivitas osteoklas, menghambat sintesis protein di osteoblas, menghambat absorpsi kalsium di usus, dan meningkatkan sekresi kalsium melalui ginjal sehingga terjadi hipokalsemia. Pada keadaan klinis sepsis yang memburuk maka akan meningkatkan kadar proinflamasi sehingga produksi glukokortikoid meningkat dan menyebabkan kadar kalsium semakin rendah (hipokalsemia bertambah berat)..$^{8,12,13}$

Selain itu, ditemukan juga sepsis awitan lanjut dan berat badan $<2500$ gram pada prognosis sepsis neonatal. Sepsis awitan lanjut mempunyai faktor risiko untuk meningkatkan terjadinya prognosis buruk 44,86 kali dibandingkan sepsis awitan dini. Hal tersebut sejalan dengan penelitian Leal $\mathrm{dkk}^{14}$ yang melaporkan bahwa insiden sepsis awitan dini lebih banyak, tetapi untuk angka kematian dan prognosis buruk lebih banyak terjadi pada sepsis awitan lanjut (21,3\% berbanding 5,7\%). Kuman penyebab terbanyak pada sepsis awitan lanjut adalah kuman Gram positif. Kuman Gram positif memiliki genetik protein, seperti catabolite activator protein (CAP) dan gamma-glutamil peptidase (GGP) serta menghasilkan toksin leukocidin (toksin yang memusnahkan leukosit sehingga meningkatkan efek virulensi pada bakteri. Beberapa kuman Gram positif dapat menghasilkan enzim koagulase yang berfungsi untuk menggumpalkan fibrinogen di dalam plasma darah sehingga terlindung dari fagositosis dan respon imun penderita. Selain itu, beberapa kuman Gram positif juga memproduksi enzim $\beta$-laktamase yang merusak struktur $\beta$-laktam pada penisilin sehingga resisten terhadap obat penisilin. Hal inilah yang menyebabkan sepsis awitan lanjut lebih banyak menyebabkan kematian dan berisiko tinggi untuk terjadinya prognosis buruk..$^{14,15}$ 
Pada penelitian ini, berat badan <2500 gram merupakan salah satu faktor untuk terjadinya prognosis buruk, 12,21 kali dibandingkan berat badan $>2500$ gram. Hal tersebut sesuai dengan penelitian Oswari $\mathrm{dkk}^{16}$ dan Leal $\mathrm{dkk}^{14}$ yang melaporkan bayi dengan berat lahir rendah memiliki risiko lebih tinggi prognosis buruk pada sepsis neonatal. Bayi berat lahir rendah memiliki kemungkinan sudah terkena infeksi sejak masa kandungan. Infeksi intrauterin dapat menimbulkan gangguan aliran darah uteroplasenta sehingga transpor berbagai zat yang dibutuhkan oleh janin, termasuk imunoglobulin $\mathrm{G}(\mathrm{IgG})$ yang berperan dalam pertahanan tubuh bayi di awal masa kehidupan akan terganggu. Imunoglobulin $G$ memiliki peran penting dalam pertahanan tubuh bayi terhadap infeksi bakteri, khususnya organisme Gram negatif, toksin bakteri, dan virus. ${ }^{17}$ Pada bayi dengan berat badan lahir rendah, kadar IgG saat baru lahir lebih rendah dibandingkan dengan bayi berat lahir normal, kemungkinan akibat gangguan transpor melalui plasenta dari ibu ke janin. ${ }^{14,17} \mathrm{Hal}$ inilah yang menyebabkan bayi berat badan lahir rendah lebih mudah mengalami sepsis dan berisiko tinggi untuk prognosis buruk.

Keterbatasan penelitian ini adalah jumlah sampel yang minimal. Hal tersebut terjadi mengingat keterbatasan waktu peneliti dan jumlah subjek sepsis neonatal pada bayi cukup bulan yang kurang karena sistem rujukan yang berlaku sehingga bayi yang dirawat di rumah sakit pusat rujukan dan rumah sakit level 3 adalah terbanyak bayi prematur dan sering terdapat riwayat asfiksia (yang merupakan kriteria eksklusi).

\section{Kesimpulan}

Hasil penelitian menunjukkan bahwa terdapat hubungan bermakna antara hipokalsemia dan prognosis buruk pada sepsis neonatal.

\section{Daftar pustaka}

1. WHO. WHO statistics 2011. Diakses pada 23 April 2013. Didapat dari: http://www.doh.gov.zaldocs/stats/2011/ who.pdf.

2. Departemen Kesehatan Republik Indonesia.Profil Data Kesehatan Indonesia 2011. Jakarta: Depkes RI; 2012.

3. Bagian Rekam Medik RS Dr Hasan Sadikin.Data angka kejadian penyakit pada pasien rawat inap periode Januari-Desember 2011 di RS Dr. Hasan Sadikin Bandung. Bandung: 2012.

4. Edmond K, Zaidi A. New approaches to preventing, diagnosing, and treating neonatal sepsis. PLoS Med 2012;7:1-8.

5. Edwards M. Clinical features and diagnosis of sepsis in term and late preterm infants. [document on the Internet]. 2012. Diakses 30 Desember 2012. Didapat dari: URL: www.uptodate.com

6. Dellinger RP, Levy MM, Rhodes A, Annane D, Gerlach H, Opal SM, dkk. Surviving sepsis campaign: International Guidelines for Management of Severe Sepsis and Septic Shock: 2012. Crit Care Med 2013;41:580-637.

7. Moritoki E, Inbyung K, Alistair N, Edward S, Craig JF, Graeme $\mathrm{KH}$, dkk. Ionized calcium concentration and outcome in critical illness. Crit Care Med 2011;39:31421.

8. G'dek-Michalska A, Tadeusz J, Rachwalska P, Spyrka J, Bugajski J. Effect of repeated restraint on homotypic stress-induced nitric oxide synthases expression in brain structures regulating HPA axis. Pharmacological Reports 2012;64:1381-90.

9. Dewi R, Rohsiswatmo R. Faktor yang memengaruhi angka kejadian hipokalsemia di ruang rawat neonatal. J Indon Med Assoc 2012;62:386-90.

10. Spasojevic I, Obradovic B, Spasic S. Bench-to-bedside review: Neonatal sepsis - redox processes in pathogenesis. Crit Care 2012;221:1-10.

11. Reinhart K, Bauer M, Riedemann NC, Hartog CS. New approaches to sepsis: molecular diagnostics and biomarkers. Clin Microb Rev 2012;25:609-34.

12. Ashish J, Ramesh A, Jeeva S, Ashok D, Vinod K. Hypocalcemia in the newborn. Indian J Pediatr 2010;77:1123-8.

13. Alphonsus N. Early-onset neonatal hypocalcaemia among full-term infants with severe birth asphyxia. J Clin Metabolism \& Diabetes 2012;3:1-4.

14. Leal Y, Alvarez-Nemegyei J, Velazquez J, Rosado-Quiab U, Diego-Rodriguez N, Paz-Baeza E, dkk. Risk factors and prognosis for neonatal sepsis in southeastern Mexico: analysis of four year historic cohort follow up. J Biomedcentral [serial on the Internet] 2012. Diakses pada 15 Agustus 2013. Didapat dari: URL: www. biomedcentral.com/1471-2393/12/48.

15. Naher HS, Khamael AB. Neonatal sepsis; the bacterial causes and the risk factors. Int Res J Med Sci 2012;1:1922.

16. Oswari H, Widjaja RK, Rohsiswatmo R, Cleghorn 
G. Prognostic value of biochemical liver parameters in neonatal sepsis-associated cholestasis. J Paediatr Child Health 2013;49:6-11.
17. Utomo M. Neonatal sepsis in low birth weigth infants in Dr. Soetomo General Hospital. Indones Trop Infect Dis 2010;1:86-9. 